\title{
ENTRE PRÁTICAS E DISCURSOS: QUESTÕES DE MÉTODO NA PESQUISA DA HISTÓRIA DO ENSINO DO DESENHO
}

\author{
Prof. Dr. Renato Palumbo Dória ${ }^{1}$
}

Além de um dos primeiros historiadores da arte, Giorgio Vasari foi, também, pioneiro no colecionismo do desenho, relacionando-se sua refletida ação na escolha e conservação de determinadas obras gráficas; além de suas inúmeras outras incumbências a serviço dos Médicis; à produção de seus textos sobre os artistas de sua época. A história da arte teria portanto a característica, já em suas origens - levando-se em conta ainda as narrativas de Plínio sobre a arte antiga, nas quais não se descuidam dos aspectos técnicos e materiais dos objetos artísticos - de não definir, aprioristicamente, uma oposição entre práticas e discursos. Oposição esta recorrente em determinadas vertentes da historiografia política e social, e presente mesmo na historiografia contemporânea da arte, que freqüentemente deixa de perceber que não se está apenas a produzir um discurso (o histórico) sobre outro discurso (o artístico), mas que estão em jogo, também, objetos e práticas muito concretas.

Em função de sua potencialidade desagregadora, este falso dilema entre práticas e discursos, apesar de aparentemente simplório, merece ainda atenção, sendo necessário rememorarmos continuamente que, na atividade do historiador da arte, as idéias e discursos em jogo estão irmanados a práticas e objetos bem determinados. Dentre nossos procedimentos historiográficos está, portanto, o necessário enfrentamento daqueles lugares comuns que inevitavelmente pontuam, e que por vezes definem a contraluz, os territórios em que se pretende penetrar. Em nossa pesquisa, sobre a história do ensino do desenho no Brasil do século XIX, estes lugares comuns apresentaram-se, frequentemente, através dos questionamentos feitos pelos próprios colegas: - De que tipo de desenho trata o trabalho? Do desenho arquitetônico? Do desenho artístico? Do desenho do nu?... Aonde? Na Academia de Belas Artes? Nos Liceus de Artes e Ofícios?... A pesquisa tratará das práticas do ensino do desenho ou dos discursos relativos a este ensino?... E aqui a primeira dentre as muitas armadilhas oferecidas ao historiador: buscar respostas a perguntas já prontas, sem perceber que estas perguntas são, também, afirmações sobre determinados temas. Tentemos então evitar o ardil, respondendo não às perguntas feitas, mas às afirmações nelas contidas (os lugares-comuns em questão): primeiramente o da existência, quase que atemporal, de diferentes tipos de desenho, sendo necessário, portanto, definir-se de antemão qual o desenho a ser abordado pela pesquisa. A seguir o de que o ensino de desenho se daria exclusivamente, no período em questão, em ambientes e instituições bem delimitadas - pensando-se, sobretudo, na ação pedagógica da Academia de Belas Artes do Rio de Janeiro. E, por fim, o de que haveriam duas distintas esferas a serem abordadas pela pesquisa, a das práticas e a dos discursos.

Uma das dificuldades do desenho, enquanto tema de investigação histórica, é a variedade de outros temas com os quais ele se comunica. Variedade ligada às suas próprias potencialidades, não se restringindo seu campo apenas às tradicionais três artes do desenho pintura, escultura e arquitetura. Ou seja: embora linguagem e conhecimento específico, o desenho esta sempre dialogando com outros modos de linguagem e conhecimento - sendo que ao menos até fins do século XIX ainda vigorou um conceito geral do desenho. Conceito geral e abrangente que, congregando e articulando diversas práticas, modelos e metodologias, não era plenamente estável, mas sim constantemente rearticulado pelas

\footnotetext{
${ }^{1}$ Departamento de Artes da Faculdade de Artes, Filosofia e Ciências Sociais da Universidade Federal de Uberlândia (DEART/FAFCS/UFU)
} 
forças em campo, ocorrendo nele a contínua reacomodação de seus múltiplos conteúdos. Buscando compreender a circulação dos conhecimentos do desenho no Brasil do século XIX em acordo com este conceito abrangente - ultrapassando assim um panorama bastante irregular e fragmentário, pleno de silêncios e vazios; e inexistindo um corpus documental coeso e disponível sobre estes assuntos - elegemos como fonte documental de nossa pesquisa os variados tipos de publicações destinadas ao ensino do desenho, editadas e utilizadas no país no século XIX. Publicações que, sendo fundamentais para a circulação em jogo, atuavam como vetores nos quais se embaralhavam as fronteiras entre práticas e discursos. Esta escolha implicou em dificuldades particulares na busca, nas bibliotecas e arquivos disponíveis, destes documentos. Dificuldades ligadas, entre outros fatores, à freqüente ambigüidade existente nos títulos destas obras, ou à sua organização sob a forma de álbuns de estampas - tendendo estes a desagregação e ao desaparecimento decorrente de seu próprio uso. Estas publicações, dirigidas frequentemente a um público relativamente amplo, e ligando-se ao princípio iluminista do século XVIII - segundo o qual o desenho deveria deixar de ser um conhecimento restrito a determinadas categorias profissionais, tornando-se uma linguagem universal e acessível a todos os membros da sociedade - não deixariam de expressar, também, a conformação de públicos específicos para o ensino do desenho, como jovens, mulheres, estudantes escolares ou trabalhadores, entre outros.

Sublinhando tanto as recorrências quanto singularidades das publicações analisadas, detivemo-nos também sobre as justificativas, nelas invocadas, para os métodos e modelos que propõem - justificativas geralmente dispostas em suas apresentações, prefácios e introduções. Sendo ainda estas publicações fruto, não poucas vezes, da experiência concreta de seus próprios autores, como professores e profissionais do desenho, deve-se notar porém que, independentemente de quaisquer textos nelas contidos, sua própria organização interna; em seus formatos, capítulos, conteúdos e modelos; é também um efetivo discurso sobre o desenho - expressando e estabelecendo programas, definindo e organizando conteúdos, comunicando objetivos didáticos, estas obras merecem uma análise conjunta de seu projeto gráfico e editorial, estando sua materialidade conectada a seus objetivos e estratégias.

Como contraponto a estes gêneros de documentos, e buscando verificar as aplicações das indicações neles contidas, efetuamos ainda, concomitantemente, um levantamento de desenhos contemporâneos às publicações registradas, e realizados em contextos claros de aprendizagem. Desenhos nos quais são, por vezes, evidentes as fontes e modelos utilizados. Esta valorização do trato direto com as fontes documentais, entretanto, em suas múltiplas camadas de significação, não desconsiderou as tensões potencialmente existentes entre práticas e discursos, não bastando aqui apenas declarar-se adepto de uma nova história - mais flexível e atenta aos gestos cotidianos, aos personagens anônimos e; sem desconsiderar estruturas sociais e ideológicas mais amplas; supostamente mais sensível às dimensões simbólicas e subjetivas. A tensão entre práticas e discursos não cessa com uma declaração de princípios, mas deve ser enfrentada continuamente, no desenrolar do próprio trabalho.

Quanto às publicações do desenho - ferramentas fundamentais dos modernos processos de ensino, conservando e transmitindo não apenas saberes específicos, mas também complexos sistemas de valores ideológicos - vale ressaltar tratarem-se de objetos que existem para além de sua materialidade e temporalidade imediatas, surgindo de decisões precedentes e não pertencendo, efetivamente, a uma só época ou autor, pois os anos neles impressos, e os nomes que os assinam, remetem a uma infinidade de outros tempos e 
autores contidos em seus interiores - alguns ocultos, outros desvelados, mas todos relevantes. Não sendo puras idéias, mas seres quase orgânicos; com suas folhas que se dobram e amarelam, que secam, quebram e caem; estes objetos singulares também têm seus momentos de fecundação e reprodução, de maturidade e envelhecimento, nascendo continuamente de obras anteriores e estabelecendo com elas longas genealogias. A pesquisa sobre estas fontes documentais, em arquivos muitas vezes mal organizados e de difícil acesso, não pode ser confundida, deste modo, com um procedimento apenas empírico, mas compreendida, sim, como um mergulhar na corrente das idéias, fatos e objetos que se quer apreender. Ainda que evidentes, neste caso, as necessidades de maiores embasamentos quanto aos possíveis procedimentos da história da arte, é preciso saber evitar, também, as artimanhas e tautologias do discurso metodológico, devendo desconfiar-se não só dos excessos de intuição - que por vezes norteiam as práticas do connoisseur - mas também do caráter supostamente científico e imparcial que parece guiar o pensamento de alguns historiadores profissionais. 